\title{
Article 26. Conference of the Parties Serving as the Meeting of the Parties to this Protocol
}

1. The Conference of the Parties shall serve as the meeting of the Parties to this Protocol.

2. Parties to the Convention that are not Parties to this Protocol may participate as observers in the proceedings of any meeting of the Conference of the Parties serving as the meeting of the Parties to this Protocol. When the Conference of the Parties serves as the meeting of the Parties to this Protocol, decisions under this Protocol shall be taken only by those that are Parties to it.

3. When the Conference of the Parties serves as the meeting of the Parties to this Protocol, any member of the Bureau of the Conference of the Parties representing a Party to the Convention but, at that time, not a Party to this Protocol, shall be substituted by a member to be elected by and from among the Parties to this Protocol.

4. The Conference of the Parties serving as the meeting of the Parties to this Protocol shall keep under regular review the implementation of this Protocol and shall make, within its mandate, the decisions necessary to promote its effective implementation. It shall perform the functions assigned to it by this Protocol and shall:

(a) Make recommendations on any matters necessary for the implementation of this Protocol;

(b) Establish such subsidiary bodies as are deemed necessary for the implementation of this Protocol;

(c) Seek and utilize, where appropriate, the services and cooperation of, and information provided by, competent international organizations and intergovernmental and non-governmental bodies;

(d) Establish the form and the intervals for transmitting the information to be submitted in accordance with Article 29 of this Protocol and consider such information as well as reports submitted by any subsidiary body;

(e) Consider and adopt, as required, amendments to this Protocol and its Annex, as well as any additional annexes to this Protocol, that are deemed necessary for the implementation of this Protocol; and 
(f) Exercise such other functions as may be required for the implementation of this Protocol.

5. The rules of procedure of the Conference of the Parties and financial rules of the Convention shall be applied, mutatis mutandis, under this Protocol, except as may be otherwise decided by consensus by the Conference of the Parties serving as the meeting of the Parties to this Protocol.

6. The first meeting of the Conference of the Parties serving as the meeting of the Parties to this Protocol shall be convened by the Secretariat and held concurrently with the first meeting of the Conference of the Parties that is scheduled after the date of the entry into force of this Protocol. Subsequent ordinary meetings of the Conference of the Parties serving as the meeting of the Parties to this Protocol shall be held concurrently with ordinary meetings of the Conference of the Parties, unless otherwise decided by the Conference of the Parties serving as the meeting of the Parties to this Protocol.

7. Extraordinary meetings of the Conference of the Parties serving as the meeting of the Parties to this Protocol shall be held at such other times as may be deemed necessary by the Conference of the Parties serving as the meeting of the Parties to this Protocol, or at the written request of any Party, provided that, within six months of the request being communicated to the Parties by the Secretariat, it is supported by at least one third of the Parties.

8. The United Nations, its specialized agencies and the International Atomic Energy Agency, as well as any State member thereof or observers thereto not party to the Convention, may be represented as observers at meetings of the Conference of the Parties serving as the meeting of the Parties to this Protocol. Any body or agency, whether national or international, governmental or non-governmental, that is qualified in matters covered by this Protocol and that has informed the Secretariat of its wish to be represented at a meeting of the Conference of the Parties serving as a meeting of the Parties to this Protocol as an observer, may be so admitted, unless at least one third of the Parties present object. Except as otherwise provided in this Article, the admission and participation of observers shall be subject to the rules of procedure, as referred to in paragraph 5 above. 


\section{Overview}

Article 26 establishes the Protocol's governing body, in accordance with a wellestablished practice under multilateral environmental agreements. ${ }^{1}$ The governing body (the Conference of the Parties to the CBD serving as the Meeting of the Parties to the Protocol, or COP/MOP) is empowered to steer and supervise the entire process of implementation and further development of the Protocol. Both areas of work will be particularly critical as several provisions of the Protocol are open-ended or require further elaboration by Parties. This provision is also noteworthy for establishing institutional and procedural linkages between the Protocol and the CBD.

The following sections will discuss the basic rules for the functioning of the $\mathrm{COP} / \mathrm{MOP}$, and its relationship with the CBD COP.

\section{The Functioning of the COP/MOP}

The Protocol's governing body comprises representatives of all States that are Party to the Protocol. It meets on a periodic basis. Article 26 thus details, in a self-explanatory manner, who is entitled to participate in the COP/MOP meetings, its bureau, the COP/MOP functions, the rules of procedure, and meetings arrangements. $^{2}$

With regards to the COP/MOP functions, Article 26(4) mirrors, as in the case of the Cartagena Protocol, ${ }^{3}$ the $\mathrm{CBD}$ provisions on the $\mathrm{COP}^{4}$ setting out the general function of the COP/MOP. These functions notably include keeping under regular review the implementation of the Protocol and making the necessary decisions to promote its implementation. Furthermore, Article 26(4) lists specific functions of the COP/MOP. The broad framing of the provision and its last open-ended clause ('exercise such other functions as may be required for the implementation of this Protocol') allow for any function needed for the

1 See for example Birnie, Boyle and Redgwell, International Law and the Environment, op. cit., 86; and Robin R. Churchill and Geir Ulfstein, "Autonomous Institutional Arrangements in Multilateral Environmental Agreements: A Little-Noticed Phenomenon in International Law," The American Journal of International Law 94 (2000): 623.

2 Mackenzie et al., Explanatory Guide to the Cartagena Protocol, op. cit., 179-184.

3 Ibid., 182.

4 Свр Article 23(4). See Glowka, Burhenne-Guilmin and Synge, Guide to the Convention on Biological Diversity, op. cit., 111-113. 
implementation of the Protocol to be carried out by the COP/MOP, even if not specifically listed.

This will be particularly useful as several issues under the Nagoya Protocol have not yet been fully resolved (for example, the determination of the need for and modalities of a global multilateral benefit-sharing mechanism, ${ }^{5}$ and the establishment of the compliance procedures and mechanisms). ${ }^{6}$ In addition, several other tasks are expressly mandated to the COP/MOP elsewhere in the Protocol (the assessment and review of the Protocol's effectiveness, ${ }^{7}$ the stocktaking of model contractual clauses and voluntary instruments, ${ }^{8}$ etc.). In these and all other cases ${ }^{9}$ in which the COP/MOP will elaborate consensus guidance on the interpretation and application of the Protocol, it will have to be guided by the Protocol objective - achieving equity and fairness in benefitsharing among States and towards indigenous and local communities, with a view to contributing to conservation and sustainable use..$^{10}$

According to Article 26, the CBD Rules of Procedure ${ }^{11}$ and Financial Rules ${ }^{12}$ are applicable to the Protocol COP/MOP, with modifications if necessary to adapt them to the specificities of the Protocol, unless the COP/MOP by consensus decides otherwise or if the Protocol itself establishes otherwise. ${ }^{13}$

As in the context of the $\mathrm{CBD},{ }^{14}$ non-Parties to the Protocol that are Parties to the CBD will be allowed to participate in the COP/MOP meetings as observers with the possibility to make interventions and submit proposals, but without

$5 \quad$ See this commentary on Article 10.

6 See this commentary on Article 30.

7 See this commentary on Article 31.

8 See this commentary on Articles 19-20.

9 Several have been identified in this commentary, such as on Articles 2-6, 8-9, 11, 14 and $16-18$.

$10 \quad$ See this commentary on Article 1.

11 Свр Decision 1/6, "Financing of and budget for the Convention" (28 February 1995) Un Doc UneP/CвD/COP/1/17, as amended by свD Decision 3/1, "Pending issues arising from the work of the second Meeting of the Conference of the Parties" (11 February 1997) UN Doc Unep/СвD/сор/3/38, Appendix - adopted under свD Article 23. See also Glowka, Burhenne-Guilmin and Synge, Guide to the Convention on Biological Diversity, op. cit., 101.

12 "Rules of procedure for meetings of the Conference of the Parties to the Convention on Biological Diversity" in СвD Decision 1/1, "Rules of procedure for the Conference of the Parties" (28 February 1995) un Doc Unep/свD/COP/1/17, Annex, as amended by СвD Decision 5/20, "Operations of the Convention" (22 June 2000) Un Doc UneP/CBD/ сор $/ 5 / 23$ (hereinafter, СвD Rules of Procedure).

13 Mackenzie et al., Explanatory Guide to the Cartagena Protocol, op. cit., 183.

14 СвD Article 32(2). See Glowka, Burhenne-Guilmin and Synge, Guide to the Convention on Biological Diversity, op. cit., 124. 
the right to vote. ${ }^{15}$ As the СвD сор serves as the Meeting of the Parties to the Protocol, the bureau of the COP will serve as the bureau of the COP/MOP. The bureau performs functions supporting the meetings of the COP/MOP, such as providing guidance to the Secretariat for the preparation and conduct of meetings; organizing the conduct of meetings; and chairing informal negotiations during meetings. ${ }^{16}$

Any governmental or non-governmental body - a term broadly interpreted under the СвD to include environment, consumer or development organizations, indigenous peoples' groups, academic or research institutions, industry associations or individual companies ${ }^{17}$ - may apply to the Secretariat for observer status. This is granted if the body in question is qualified in matters covered by the Protocol, and unless one-third of the Parties present at a particular meeting objects - that is, Parties attending that meeting and only with respect to the presence of a non-governmental body or agency at that meeting. So the acceptance or rejection of a body or agency is only valid for that particular meeting. ${ }^{18}$

\section{$3 \quad$ Relationship with the CBD COP}

Article 26, similarly to the Biosafety Protocol, ${ }^{19}$ clarifies the relationship between the Protocol's governing body and the СвD сор. Since the Protocol is a separate legal instrument, the functions of the COP/MOP differ to some extent from those of the СвD СOP, and the membership of the two bodies is not necessarily the same. Not all Parties to the СвD (who are represented in the CBD COP) may decide to become Parties to the Protocol. ${ }^{20}$

15 Note that Rule 40 on voting in the CвD Rules of Procedure remains bracketed, so no voting takes place at Свр meetings. For a similar discussion in relation to the Biosafety Protocol, see Mackenzie et al., Explanatory Guide to the Cartagena Protocol, op. cit., 181.

16 Greiber et al., Explanatory Guide, op. cit., 230. For a similar discussion in relation to the Biosafety Protocol, see Mackenzie et al., Explanatory Guide to the Cartagena Protocol, op. cit., 181.

17 Ibid.

18 The steps to apply for and attain observer status at meetings under the Convention are detailed in свр Decision 9/29, "Operations of the Convention," (9 October 2008) UN Doc $\mathrm{UNEP} / \mathrm{CBD} / \mathrm{COP} / 9 / 29$, paragraph 17 . For a similar discussion in relation to the Biosafety Protocol, see Mackenzie et al., Explanatory Guide to the Cartagena Protocol, op. cit., 184.

19 Biosafety Protocol Article 29.

20 For a similar discussion in relation to the Biosafety Protocol, see Mackenzie et al., Explanatory Guide to the Cartagena Protocol, op. cit., 180. 
There is, however a significant difference concerning the link between the СBD COP and the Protocol COP/MOP, when comparing the Cartagena and the Nagoya Protocols. ${ }^{21}$ The negotiators' main concern was to ensure that the institutional structure of the Nagoya Protocol remains well linked to that of the $\mathrm{CBD}$, as opposed to the case of the Biosafety Protocol, which has turned into quite a separate process from the $\mathrm{CвD} .{ }^{22}$ The rationale lays in the recognition that benefit-sharing is both the objective of the Protocol as well as the third objective of the СвD. ${ }^{23}$ In addition, several areas of work under the СвD would continue to be directly relevant for the effective implementation of the Nagoya Protocol. ${ }^{24}$ The negotiators therefore discussed the possibility to follow the example of the Kyoto Protocol under the UN Framework Convention on Climate Change, ${ }^{25}$ and provide for the Protocol governing body's meetings to be held concurrently, rather than in conjunction, with the СвD сор. ${ }^{26}$ In other words, instead of being held back-to-back, as is the case for the Свр СОР and the Biosafety COP/MOP, the meetings of the Nagoya Protocol's governing body will be held simultaneously with those of the СвD СоP. ${ }^{27}$ It can be expected that the agendas of the two meetings will be developed so to maximize synergies and avoid repetitive discussion on closely related agenda items.

Nevertheless, the COP/MOP is a distinct and independent body from the СвD СОР for all practical purposes, including guidance to the financial mechanism ${ }^{28}$ and in relation to the costs of Secretariat services to the extent that they cannot be split up between the CвD and the Nagoya Protocol. ${ }^{29}$

21 Compare Biosafety Protocol Article 29(6). See also. Greiber et al., Explanatory Guide, op. cit., 232-233.

22 Morgera and Tsioumani, "Yesterday, Today, and Tomorrow," op. cit., 36.

23 See Introduction to this commentary, section 1.3.

24 For instance the work programmes on Article $8(\mathrm{j})$, protected areas, and communication, education and public awareness.

25 Kyoto Protocol to the United Nations Framework Convention on Climate Change (Kyoto, 11 December 1997, in force 16 February 2005) 2303 unts 148 (hereinafter, Kyoto Protocol).

26 ENB, "Tenth Meeting of the Conference of the Parties to the Convention on Biological Diversity: 18-20 October 2010," Vol. 9 No. 534, 18 October 2010, 4.

27 Greiber et al., Explanatory Guide, op. cit., 232.

28 See this commentary on Article 25, section 2.

29 See this commentary on Article 28. 